\title{
Effect of Plant Growth-Promoting Rhizobacteria at Various Nitrogen Rates on Corn Growth
}

\author{
Yaru Lin', Dexter B. Watts ${ }^{*}{ }^{\circledR}$, Joseph W. Kloepper ${ }^{3}$, Anthony O. Adesemoye ${ }^{4}$, Yucheng Feng1 \\ ${ }^{1}$ Department of Crop, Soil, and Environmental Sciences, Auburn University, Auburn, AL, USA \\ ${ }^{2}$ USDA-ARS, National Soil Dynamics Laboratory, Auburn, AL, USA \\ ${ }^{3}$ Department of Entomology and Plant Pathology, Auburn University, Auburn, AL, USA \\ ${ }^{4}$ Department of Plant Pathology, WCREC, University of Nebraska Lincoln, Lincoln, NE, USA \\ Email: ^Dexter.Watts@ars.usda.gov
}

How to cite this paper: Lin, Y.R., Watts, D.B., Kloepper, J.W., Adesemoye, A.O. and Feng, Y.C. (2019) Effect of Plant GrowthPromoting Rhizobacteria at Various Nitrogen Rates on Corn Growth. Agricultural Sciences, 10, 1542-1565.

https://doi.org/10.4236/as.2019.1012114

Received: October 10, 2019

Accepted: December 8, 2019

Published: December 11, 2019

Copyright $\odot 2019$ by author(s) and Scientific Research Publishing Inc. This work is licensed under the Creative Commons Attribution International License (CC BY 4.0).

http://creativecommons.org/licenses/by/4.0/

\begin{abstract}
Plant growth-promoting rhizobacteria (PGPR) colonize plant roots and promote plant growth by producing and secreting various chemical regulators in the rhizosphere. With the recent interest in sustainable agriculture, an increasing number of researchers are investigating ways to improve the efficiency of PGPR use to reduce chemical fertilizer inputs needed for crop production. Accordingly, greenhouse studies were conducted to evaluate the impact of PGPR inoculants on biomass production and nitrogen $(\mathrm{N})$ content of corn (Zea mays L.) under different $\mathrm{N}$ levels. Treatments included three PGPR inoculants (two mixtures of PGPR strains and one control without PGPR) and five $\mathrm{N}$ application levels $(0 \%, 25 \%, 50 \%, 75 \%$, and $100 \%$ of the recommended $\mathrm{N}$ rate of $135 \mathrm{~kg} \mathrm{~N} \mathrm{ha}^{-1}$ ). Results showed that inoculation of PGPR significantly increased plant height, stem diameter, leaf area, and root morphology of corn compared to no PGPR application under the same N levels at the V6 growth stage, but few differences were observed at the V4 stage. PGPR with $50 \%$ of the full $\mathrm{N}$ rate produced corn biomass and $\mathrm{N}$ concentrations equivalent to or greater than that of the full $\mathrm{N}$ rate without inoculants at the VT stage. In conclusion, mixtures of PGPR can potentially reduce inorganic $\mathrm{N}$ fertilization without affecting corn plant growth parameters. Future research is needed under field conditions to determine if these PGPR inoculants can be integrated as a bio-fertilizer in crop production nutrient management strategies.
\end{abstract}

\section{Keywords}

Plant Growth-Promoting Rhizobacteria, Corn Growth, Nitrogen

Fertilization, Root Morphology, Nitrogen Use Efficiency 


\section{Introduction}

Commercial fertilizers, especially $\mathrm{N}$ sources, are essential for maintaining global crop production and fulfilling food requirements for a rapidly growing world population with limited land resources [1] [2] [3] [4]. In 2014, over 11.7 million tonnes of $\mathrm{N}$ fertilizer were applied to US agricultural crops [5]. This number is expected to increase in the coming years because inorganic $\mathrm{N}$ is an indispensable input in crop production. For example, Stewart et al. [1] evaluated several longterm studies to determine the effect of eliminating $\mathrm{N}$ fertilizer, and predicted that corn and cotton (Gossypium hirsutum L.) yields would decline by $41 \%$ and $37 \%$, respectively, without $\mathrm{N}$ fertilizer. Optimal crop yields also depend upon the nitrogen use efficiency (NUE) of crops. Generally, NUE is very low ( 33\%; [6]) due to various soil processes and environmental factors [7] [8]. For example, over half of the $\mathrm{N}$ applied can be lost from agricultural systems as gaseous loss $\left(\mathrm{N}_{2}\right.$, nitrous oxide, $\mathrm{NH}_{3}$ etc.), runoff $\left(\mathrm{NO}_{3}\right)$, or leaching $\left(\mathrm{NO}_{3}\right)$ into groundwater [9] [10]. Changing this poor NUE requires more effective management practices.

Microorganisms that promote plant growth may be worth evaluating as a prospective tool to improve fertilizer use efficiency [11] [12] [13] [14] [15]. Plant growth-promoting rhizobacteria (PGPR) are free-living microbes that live on or around the roots [16] and that stimulate plant growth and enhance root development and architecture [17] [18] [19] [20]. Kumar et al. [21] reported that applying Pseudomonas aeruginosa LES4 at half the recommended fertilizer rate resulted in growth of sesame (Sesamum indicum L.) that was equivalent to treatments at the full fertilizer rate, and that the oil yield increased $33.3 \%$, and protein yield increased $47.5 \%$ compared to the full fertilizer rate. Adesemoye et al. [19] found that on tomato (Solanum lycopersicum) supplementing $75 \%$ of the recommended fertilizer with a mixture of Bacillus spp. and arbuscular mycorrhiza fungus (AMF) resulted in growth, yield, and uptake of $\mathrm{N}$ and $\mathrm{P}$ equivalent to the full fertilizer rate without inoculants. Similar results also showed that inoculating $P$. thivervalensis and Serratia marcesens to soil with $75 \%$ of the recommended chemical fertilizer rate for corn [22] and inoculating Rhodopseudomonas palustris to soil with $50 \%$ of recommended chemical fertilizer rate for Chinese cabbage (Brassica rapachinesis, [23]) resulted in the same plant biomass and yield as with the full rate.

Among the genera of PGPR, Bacillus is the most widely used to enhance plant growth and suppress plant diseases [24] due to their capacity to form stable endospores that can be inoculated onto crop seeds. Also, their wide metabolic capabilities allows them to play important roles in soil ecosystem functions and processes, such as soil carbon, nitrogen, and sulfur cycling, and transformation of other soil nutrients [25]. Huang et al. [26] isolated four Bacillus strains from rainforest soils that increased plant height and shoot biomass of Arabidopsis, corn, and tomato under greenhouse conditions. In another study, Wani and Khan [27] reported that Bacillus strains enhanced plant height and plant fresh 
weigh of tomatoes in both nutrient poor soils and soils receiving $\mathrm{N}$ fertilization. However, the range of enhancement was much lower when sufficient $\mathrm{N}$ was supplied. Inoculating plants with Bacillus strain PSB10 also resulted in enhanced nodulation, chlorophyll, leghemoglobin, seed yield, and grain protein of chickpea (Cicer arietinum L.) in chromium-stressed soils [27]. In another study, Meng et al. [28] inoculated nine types of plants under greenhouse conditions with the $B$. velezensis strain and found that some of the plants increased growth at various levels in different plant parts. Growth promotion by Bacillus has also been observed with canola (Brassica napus L., [29], corn [30], soybean (Glycine max, [31], sugar beet (Beta vulgaris, [32]), and wheat (Triticuma estivum L., [33]).

Numerous studies and reviews have reported plant growth promotion, increased yield, phytohormone production, soil $\mathrm{P}$ solubilization, and enhanced $\mathrm{N}$ uptake through inoculation with Bacillus spp. However, most of these studies were conducted using single-strain inoculations and the positive effects were only shown under specific conditions, and hence, growth promotion was limited when using single-strain inoculations [34]. For example, B. velezensis inoculation increased dry leaf weight, but not root weight for several vegetative crops [28]. In a study on canola, de Freitas et al. [29] reported that Bacillus spp. had no effect on plant growth when rock phosphate was applied; while seed yield was increased, there was no effect on P uptake with triple superphosphate. Similarly, de Freitas [33] reported in a pot study that B. polymyxa tended to enhance wheat grain yield, but no differences in total-N or shoot dry matter yield were observed as compared to the uninoculated control.

A few studies have reported that mixtures of PGPR strains generally cause more consistent positive effects on plant growth than do individual strains [35] [36] [37]. In addition, some studies have suggested that PGPR are more effective under limited nutrient conditions [26] [38] [39]. For example, a greenhouse study showed that $B$. polymyxa had a better stimulatory effect on corn plant growth and $\mathrm{N}, \mathrm{P}$, and $\mathrm{K}$ uptake in nutrient-deficient soils than in nutrient-rich soils [39]. However, limited information exists concerning the effects of Bacillus spp. mixtures on corn growth with reduced levels of $\mathrm{N}$ fertilizers. Therefore, the objectives of this study were to: 1) evaluate the impact of PGPR mixtures on corn root growth and biomass production under different $\mathrm{N}$ levels; 2) investigate the potential of PGPR mixtures to allow a reduction in the amount of inorganic $\mathrm{N}$ fertilizer needed by resulting in corn plant growth and nutrient uptake levels equivalent to those at the recommended $\mathrm{N}$ fertilizer rate; and 3) determine the optimal $\mathrm{N}$ rate for stimulating PGPR growth-promoting effects on corn.

\section{Materials and Methods}

\subsection{Greenhouse Experiment}

A greenhouse container study was conducted at Auburn University's Horticulture Paterson Greenhouse (HP) in Auburn, AL, USA. This study consisted of two separate experiments conducted with the same treatments. The first experi- 
ment was conducted from March to May and second experiment from April to June of 2017 in the same greenhouse. The soil used for this study was a Kalmia sandy loam (fine-loamy over sandy, siliceous, semiactive, thermic TypicHapludults) collected from the E.V. Smith Research Center-Plant Breeding Unit in Elmore County, near Tallassee, AL. Surface soil (0 - $15 \mathrm{~cm}$ depth) was collected in early-spring from an area that had been previously under row crop production. The soil was sieved through a $5-\mathrm{mm}$ sieve and was analyzed for nutrient concentrations according to procedures described by Hue and Evans [40]. Briefly, the soil had a pH of 5.5 , total $\mathrm{N}$ concentration of $0.5 \mathrm{~g} \cdot \mathrm{kg}^{-1}$, total C concentration of $4.8 \mathrm{~g} \cdot \mathrm{kg}^{-1}, \mathrm{P}$ concentration of $22.7 \mathrm{mg} \cdot \mathrm{kg}^{-1}, \mathrm{~K}$ concentration of 58.1 $\mathrm{mg} \cdot \mathrm{kg}^{-1}$, Ca concentration of $199 \mathrm{mg} \cdot \mathrm{kg}^{-1}$, and $\mathrm{Mg}$ concentration of 51.5 $\mathrm{mg} \cdot \mathrm{kg}^{-1}$. Based on initial soil $\mathrm{pH}$ and nutrient levels, the Alabama Agricultural Extension System recommended applying $45 \mathrm{~kg} \mathrm{P} \mathrm{ha}^{-1}, 45 \mathrm{~kg} \mathrm{~K} \mathrm{ha}^{-1}$, and 4.5 tons $\mathrm{ha}^{-1}$ limestone for corn production.

The experiment was conducted as a completely randomized design with five replications. Treatments consisted of three PGPR inoculants combined with five $\mathrm{N}$ rates. The PGPR treatments consisted of two PGPR strain mixtures (Table 1) and one control without PGPR. The strains were obtained from pure culture collections at Auburn University's Department of Entomology and Plant Pathology. These strains have positive effects on plant growth and were selected from previous screening experiments. The bacterial mixtures were prepared by mixing each strain's spore, which was previously quantified by plating the suspension on tryptic soy agar (TSA) plates and incubating for $48 \mathrm{~h}$ at $25^{\circ} \mathrm{C}$, in equal concentrations. A bacterial mixture of $1 \times 10^{6}$ spore $\mathrm{ml}^{-1}$ was used for this study. The $\mathrm{N}$ rate treatments consisted of applying $0 \%, 25 \%, 50 \%, 75 \%$, and $100 \%$ of the $135 \mathrm{~kg} \mathrm{~N} \mathrm{ha}^{-1}$ rate recommended by Alabama Cooperative Extension System for corn on a Coastal Plain soil [41]. One day prior to sowing, urea $(46 \% \mathrm{~N})$, triple superphosphate, and potassium chloride dissolved in water were added to the soil.

The experimental units consisted of plastic containers $(8 \mathrm{~L}$ Gro Pro square pots, Sunlight Supply, Inc., Vancouver, WA, USA) that were $24 \mathrm{~cm}$ tall, measured $23 \times 23 \mathrm{~cm}$ at the top, and tapered to $18 \times 18 \mathrm{~cm}$ at the base. The containers

Table 1. Bacteria species and strains present in the PGPR mixtures used in this study.

\begin{tabular}{ccc}
\hline PGPR Mix \# & Original Strain \# & Identification \\
\hline 1 & 2 RA-17 & Bacillus cereus \\
& $99-101$ & B. amyloliquefaciens \\
& $33 \mathrm{~B}-9$ & B. mojavensis \\
IN-937a & B. subtilis subsp. subtilis \\
& INR-52 & B. safensis \\
& SE-56 & B. altitudinis \\
& E-681 & Lysinibacillus xylanilyticus
\end{tabular}


were filled with $12.5 \mathrm{~kg}$ of soil and adjusted to saturation with water. Five extra containers were designated for determining saturation. Saturation was estimated by determining the average amount of water needed to fill containers until they reached a drip point (i.e., when water begins to drip from basal drain holes). Two corn seeds (P1319HR; DuPont Pioneer, Johnston, IA, USA) per container were sown in moist soil to a depth of $5 \mathrm{~cm}$. A $1 \mathrm{ml}$ suspension of the respective bacterial mixture (Bacillus spp.) was applied on top of each seed at sowing. After germination, plants were thinned to one plant per container and watered every three days to saturation. Temperature within the greenhouse was maintained at $26^{\circ} \mathrm{C} \pm 2{ }^{\circ} \mathrm{C}$ during the day and $20^{\circ} \mathrm{C} \pm 3^{\circ} \mathrm{C}$ at night. To minimize micro-environmental variation among treatments, containers were rotated weekly at random by treatment.

\subsection{Data Collection}

Corn plants were harvested at the V4, V6, and VT vegetative growth stages. Plant height, stem diameter, leaf area, leaf chlorophyll content, root morphological features, and dry shoot and root weights were measured at each harvest time. Plant height was determined by measuring from the base to the top of the newest fully developed leaf. Stem diameter was determined at the base of plant using high-precision digital calipers (MitutoyoDigimatic Caliper, Mitutoyo Corp., Kawasaki, Japan). Leaf greenness (chlorophyll content) was determined by measuring from the newest fully expanded functional corn leaf with a Minolta SPAD 502 plus (Minolta Camera Co., Ltd., Osaka, Japan). Afterwards, plants were cut at the soil surface with handheld pruning shears. Leaf area was determined from the harvested plants using an area meter (LI-3100C Area Meter, LI-COR Biosciences, Lincoln, NE, USA). All leaves from one plant were cut and placed on an area meter one by one (avoiding overlap) to determine leaf area. Root biomass was determined by carefully rinsing roots on a $0.5 \mathrm{~mm}$ mesh screen sieve. The above- or below-ground plant biomass was then placed into paper bags and dried $\left(55^{\circ} \mathrm{C}\right)$ until the weight became constant in a forced-air drying oven to determine dry weight. Before drying, roots were scanned and analyzed for root morphology using the WinRHIZO Arabidopsis software (v2009c 32 bit system, Regent Instruments, Quebec, QC, Canada) connected to an Epson XL 10,000 professional scanner (Seike Epson Corp., Shinjuku, Tokyo, Japan). Each individual root system was evenly spread apart, placed in a water bath on a transparent tray $(30 \times 40 \mathrm{~cm}$ width), and imaged at a resolution of 157.5 dots per $\mathrm{cm}$ as described by Bauhus and Messier [42] and Costa et al. [43]. The following root characteristics were determined: total root length $(\mathrm{cm})$, root surface area $\left(\mathrm{cm}^{2}\right)$, root volume $\left(\mathrm{cm}^{3}\right)$, and average root diameter $(\mathrm{mm})$. Plant total $\mathrm{N}$ was determined on the dried shoot and root tissues. Ground plant tissues $(0.2 \mathrm{~mm}$ mesh) of leaves, stems, and roots harvested at the VT stage were analyzed for $\mathrm{N}$ using the dry combustion method (LECO FP-528 Nitrogen/Protein Analyzer, LECO Corp., Saint Joseph, MI, USA). 


\subsection{Data Analysis}

An analysis of variance (ANOVA), using a general linear model (GLM) of SAS 9.4 [44], was used to analyze each response variable in this experiment. The least significant difference test (LSD) at a 0.05 probability level was used to identify significant differences among treatments. Significant interactions $(P \leq 0.05)$ were observed between the two experiments and the $\mathrm{N}$ rates. Thus, treatment means for each $\mathrm{N}$ rate were analyzed separately by experiment. Significant interactions between $\mathrm{N}$ rate and PGPR treatments $(P \leq 0.05)$ were observed for some response variables, thus, the LSD test was conducted to identify significant difference among PGPR treatments at each $\mathrm{N}$ level for these response variables. Also, comparisons were made to determine the effects of each PGPR inoculant at each $\mathrm{N}$ level to the non-inoculated full $\mathrm{N}$ rate treatment (standard application rate) using the LSD test.

\section{Results and Discussion}

\subsection{Plant Growth Parameters}

Plant height is often correlated with the number of leaves per plant and can potentially affect corn yield [45]. Nitrogen levels significantly affected the corn vegetative growth parameters evaluated (plant height, stem diameter, and leaf area) in this study from the V4 to VT stages (Table 2 and Table 3). There were no significant differences in either experiment or clear tendencies observed among the $\mathrm{N}$ levels evaluated for plant height at the V4 and VT stages in either experiment. Plants receiving $75 \%(P=0.0052)$ and $100 \%(P=0.0327)$ of the recommended $\mathrm{N}$ rate were significantly taller than those with no $\mathrm{N}$ application at the V6 stage in the first experiment (HP1). Our results were consistent with previous studies, which showed that the tallest plants were observed with the application of approximately $70 \%$ of recommended $\mathrm{N}$ rate [46] [47]. Arnon [48] indicated that shorter plants resulting from low $\mathrm{N}$ availability may be associated with delayed cell division at the growing points. In addition to nutrient content of soil, plant height is also influenced by soil moisture, temperature, sunlight duration, and other environmental factors. Soil moisture and temperature were suitable for plant growth under the greenhouse conditions of this study, and thus, all plants had normal plant height irregardless of $\mathrm{N}$ levels. Significant effects of microbial inoculations (averaged across $\mathrm{N}$ rates) on plant height were only observed at the V6 stage in HP1 (Table 2), in which, PGPR strain mixture 1 increased plant height on average by $6.8 \%$ and $11.0 \%$ compared to the no-PGPR ( $P$ $=0.0534)$ and PGPR strain mixture $2(P=0.0073)$, respectively. Although there were no statistical differences between PGPR inoculants and non-inoculated treatments at the V4 and VT stages for either experiments (Table 2 and Table 3), PGPR inoculations tended to increase plant height during these growth stages. For example, the tallest plant was observed for PGPR mixture 1 when combined with $25 \%$ of recommended $\mathrm{N}$ rate $(\mathrm{N} 25 \mathrm{P} 1)$ at the $\mathrm{V} 4$ stage, $50 \%$ of 


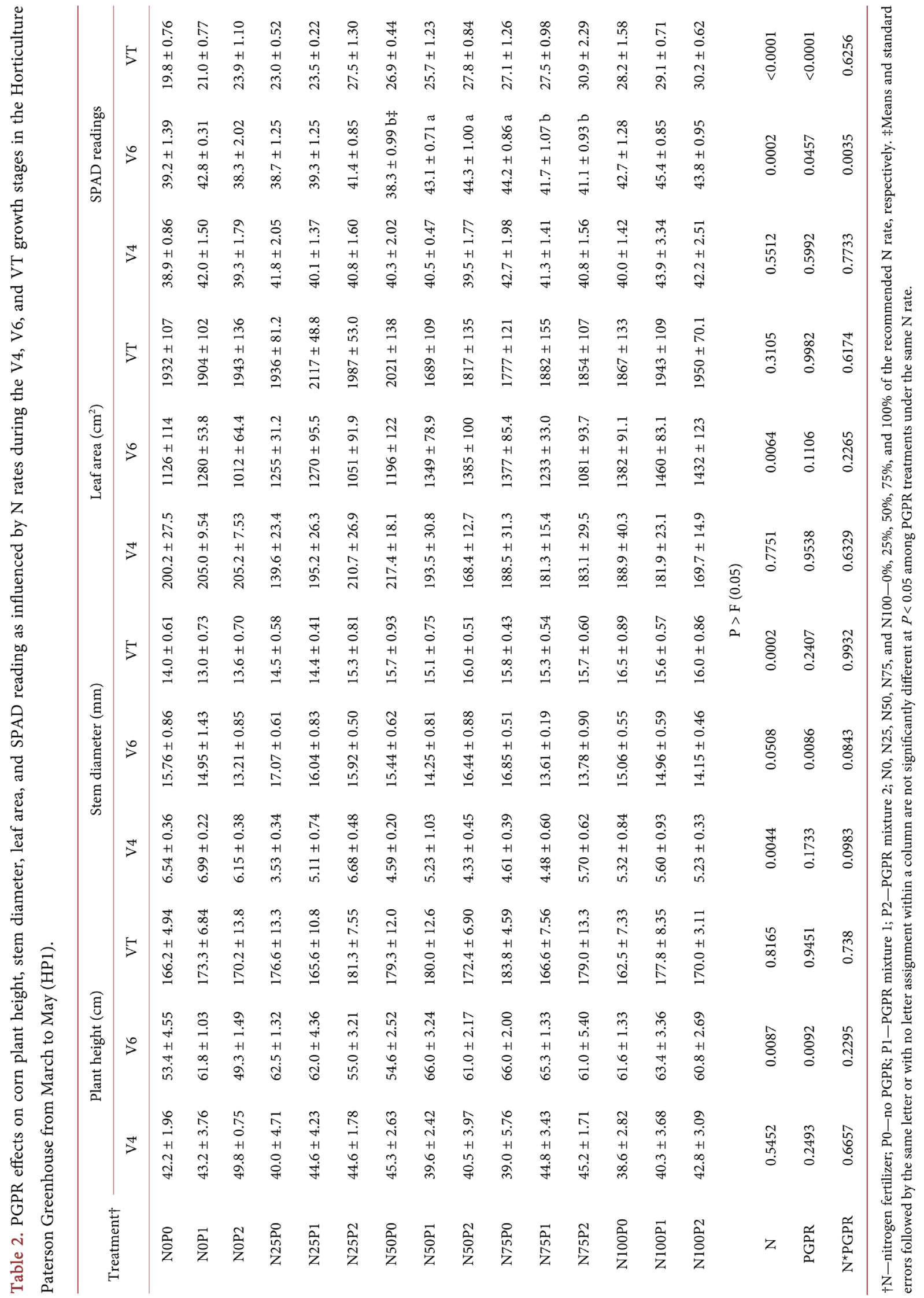




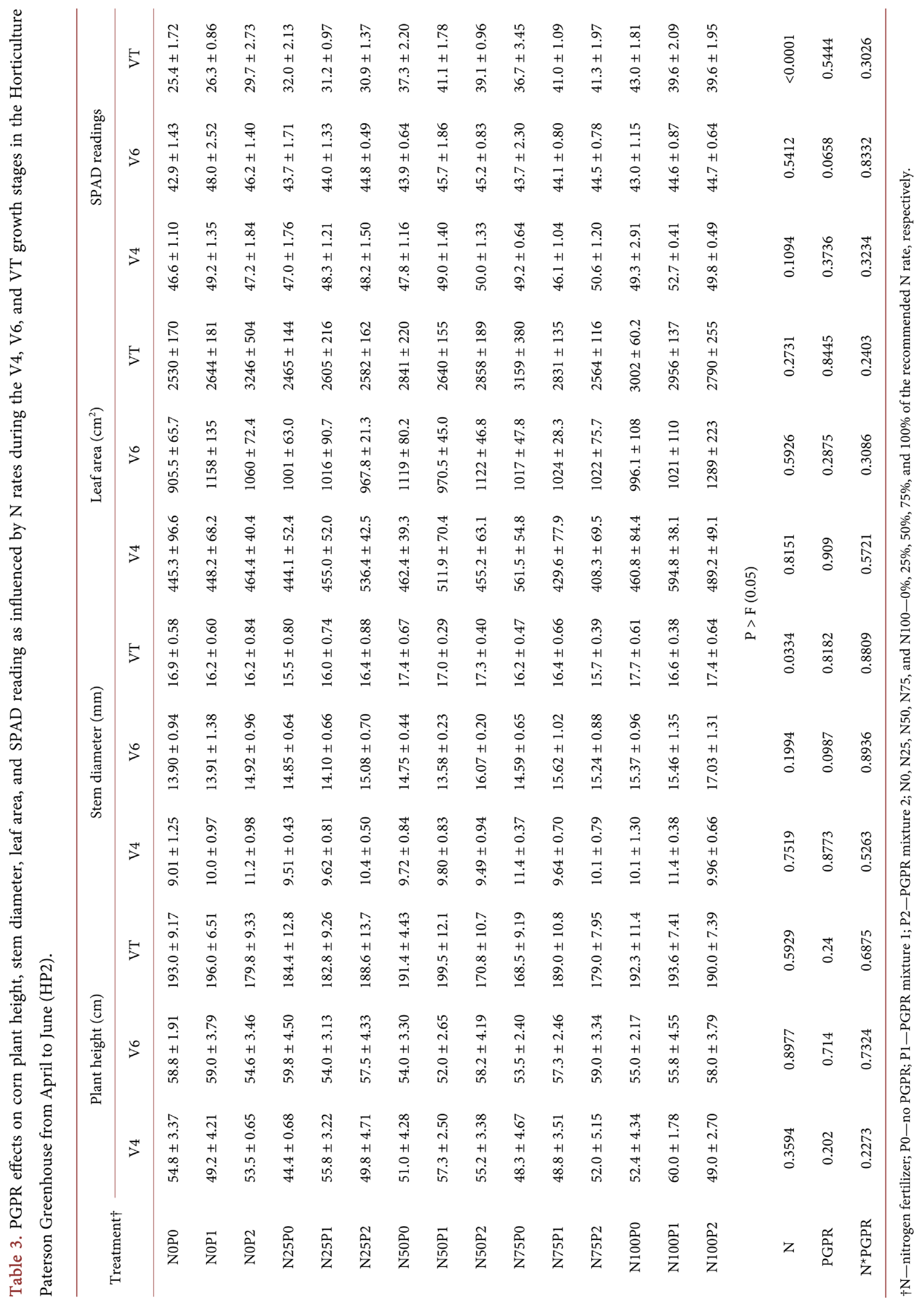


recommended $\mathrm{N}$ rate $(\mathrm{N} 50 \mathrm{P} 1)$ at the VT stage, and $100 \%$ of recommended $\mathrm{N}$ rate (N100P1) at the V4 stage in HP2, when compared to the other PGPR treatments evaluated using the same $\mathrm{N}$ rate (Table 3). Moreover, inoculation of the PGPR mixture 2 significantly increased plant height compared to the N100P0 treatment $(P=0.0260)$ at the V4 stage in HP1 (Table 2).

Stem diameter was significantly affected by $\mathrm{N}$ levels, especially during the latter vegetative growth stages (Table 2 and Table 3$)$. Plants grown with $50 \%(P=$ $0.0042), 75 \%(P=0.0050)$, and $100 \%(P=0.0002)$ of the recommended $\mathrm{N}$ rate had significantly greater stem diameter than the no $\mathrm{N}$ control at the VT stage during HP1, with an increase of $15.2 \%, 14.9 \%$, and $18.4 \%$, respectively. Nitrogen rate also significantly affected corn stem diameter at the VT stage in HP2, and plants with $100 \%$ of the recommended $\mathrm{N}$ rate had the largest stems. Although, there were no significant differences among $\mathrm{N}$ treatments for stem diameter at the V4 and V6 stages in HP2, there was a tendency for greater stem diameter with increasing $\mathrm{N}$ rates. Fancelli and DouradoNeto [49] reported that stronger stems were directly related to increased productivity since it is involved in the storage of soluble solids, which may subsequently be used in the formation of seeds. PGPR inoculations (averaged across $\mathrm{N}$ rates) had minimal impact on stem diameter of corn, no significant difference was observed at the V4 and VT stages and a significant decrease in stem diameter was observed at the V6 stage in HP1 (Table 2 and Table 3). However, when conducting direct comparisons between each PGPR mixture at each N level, PGPR mixture 1 at the V4 stage in HP1 tended to increased stem diameter for the no $\mathrm{N}$ fertilizer (NOP1) treatment, and was even significantly greater than that of the N100P0 (recommended $\mathrm{N}$ rate without PGPR) treatment ( $P=0.0467)$.

There were no significant differences among $\mathrm{N}$ levels on leaf area at the V4 and VT stages for both experimental times (Table 2 and Table 3). However, average leaf area at the recommended $\mathrm{N}$ rate was significantly larger than that the no $\mathrm{N}$ fertilizer $(P=0.0013)$ or $25 \%$ of recommended $\mathrm{N}$ rate treatment $(P=$ $0.0005)$ at the V6 stage in HP1. The leaf area was not influenced by PGPR applications for both experiments (Table 2 and Table 3), while PGPR inoculations showed an increasing tendency at some $\mathrm{N}$ levels.

Leaf greenness (SPAD readings) was significantly affected by N levels at V6 in HP1 and at the VT stage during both experiments (Table 2 and Table 3). SPAD readings increased with increasing $\mathrm{N}$ rates throughout the plant growth stages; therefore, higher chlorophyll content was observed when relatively high $\mathrm{N}$ fertilizer rates were applied. The effects of microbial inoculations on leaf greenness varied depending on growth stage and $\mathrm{N}$ level for both experiments (Table 2 and Table 3).

Significant differences were observed between PGPR inoculants at the V6 and VT stages in HP1. An interaction of N level and PGPR inoculation was observed for SPAD readings at the V6 stage in HP1. A significant increase in chlorophyll content was observed after inoculation of PGPR mixtures $1 \& 2$ when $50 \%$ of the recommended $\mathrm{N}$ rate $(P=0.0322)$ was compared to the no-PGPR control at the 
same $\mathrm{N}$ rate. When conducting direct comparisons between each PGPR mixture at each N level, PGPR mixture 1 at the V6 stage $(P=0.0398)$ and PGPR mixture 2 at the VT stage $(P<0.0001)$ had significantly greater SPAD readings than the non-inoculated control, with an increase of $4.5 \%$ and $12.3 \%$, respectively. Moreover, PGPR mixture 1 with no $\mathrm{N}$ application (N0P1; direct comparison between each PGPR at each $\mathrm{N}$ level) had the greatest leaf area compared to other treatments, and was significantly greater than that of the N100P0 treatment $(P=$ 0.0183 ) at the V6 stage in HP2.

The uptake of $\mathrm{N}$ by corn is low during early development and increases as it nears tasseling [50], which means that $\mathrm{N}$ generally has minimal effects on plant growth during the seedling stages. This likely is why minimal differences were observed for the plant growth parameters at the V4 stage. Moreover, another important factor that may affect seedling growth is the emergence day. Earlier emergence can lead to taller plants, greater stem diameter, and leaf area. Since temperature and sunlight duration increased from March to June; therefore, greater plant growth parameters (plant height, stem diameter, and leaf area) were found in HP2, rather than in HP1.

Overall, applying PGPR had positive effects on plant growth during the vegetative stages, especially at the V6 stage when corn plants' need for $\mathrm{N}$ from soil begins to escalate. In this study, PGPR mixture 1 showed positive effects on plant height, stem diameter, and leaf greenness of corn, while PGPR mixture 2 tended to only increase leaf area and leaf greenness of corn. The difference between these two microbial inoculated mixtures may be due to the capacity of the different Bacillus spp. responses to the soil N conditions. Our results are consistent with previous studies which indicated that PGPR can increase plant height [37] [51] [52], increase plant stem diameter [53] [54], and enhance the number of leaves and leaf area of corn [55] [56]. Most of these improvements in plant growth were observed prior to the corn reaching the tasseling stage. In this study, PGPR showed more positive effects under low $\mathrm{N}$ soils than the soil with high rates of $\mathrm{N}$ fertilization. Consistently, several studies have demonstrated that when nutrient levels are high in soil, PGPR's efficacy to improve plant growth is low [12] [57] [58]. One possible reason is that the production of ethylene under low levels of nutrients could be catabolized by 1-aminocyclopropane-1-carboxylate (ACC) deaminase, produced by PGPR, to $\mathrm{NH}_{3}$ and a-ketobutyrate [59]. In addition, in nutrient rich soil, plants could obtain enough $\mathrm{N}$ from soil by their own root absorption, thus, plants will not need rhizobacteria-enhanced $\mathrm{N}$ uptake.

\subsection{Root Morphology}

The influence of PGPR inoculants on root morphological parameters varied with $\mathrm{N}$ level and growth stage (Table 4 and Table 5). A significant $\mathrm{N}$ and PGPR interaction was observed for total root length at the V6 and VT stages in HP2 (Table 5), showing that PGPR inoculates had a positive effect on total root length at 


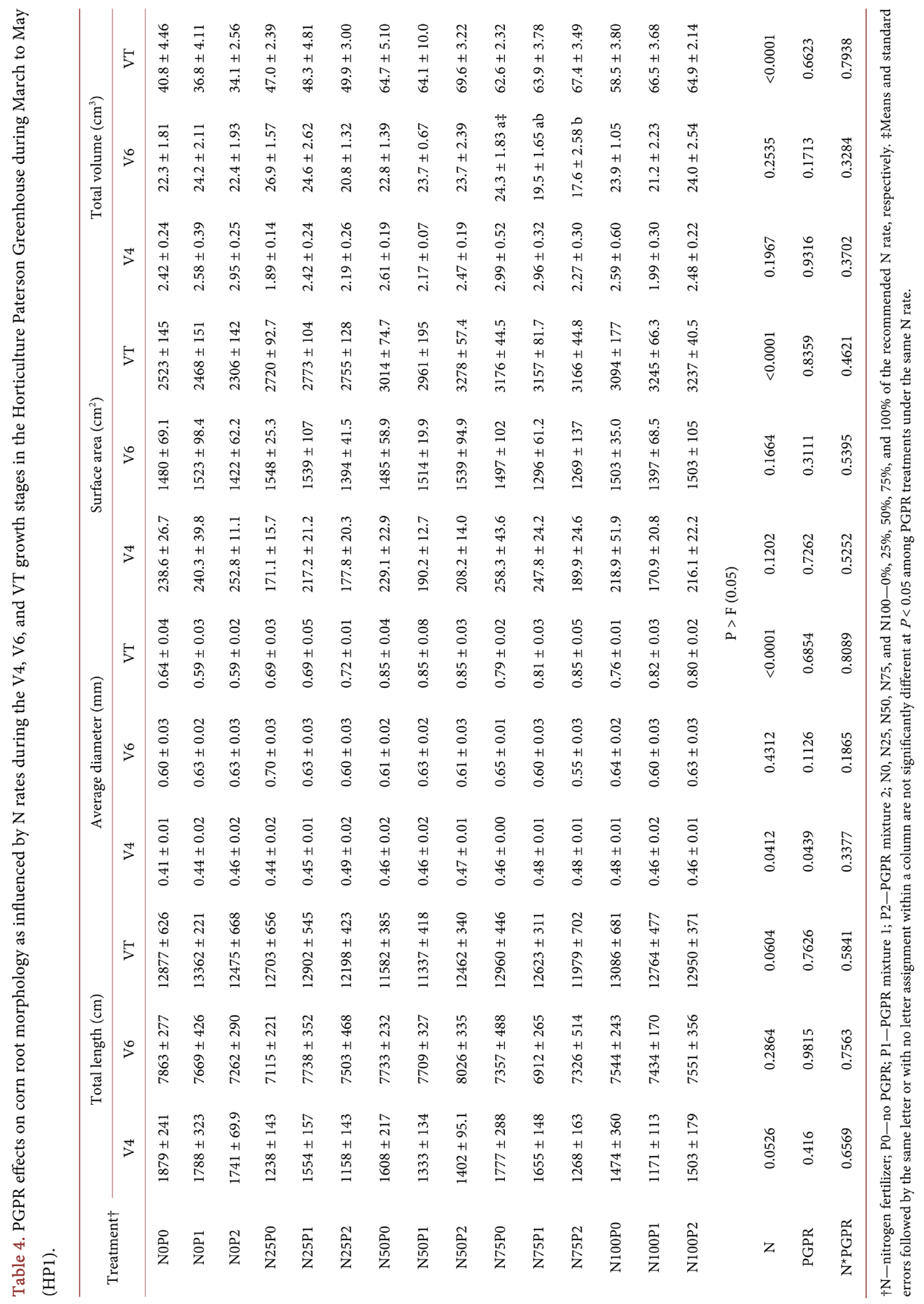




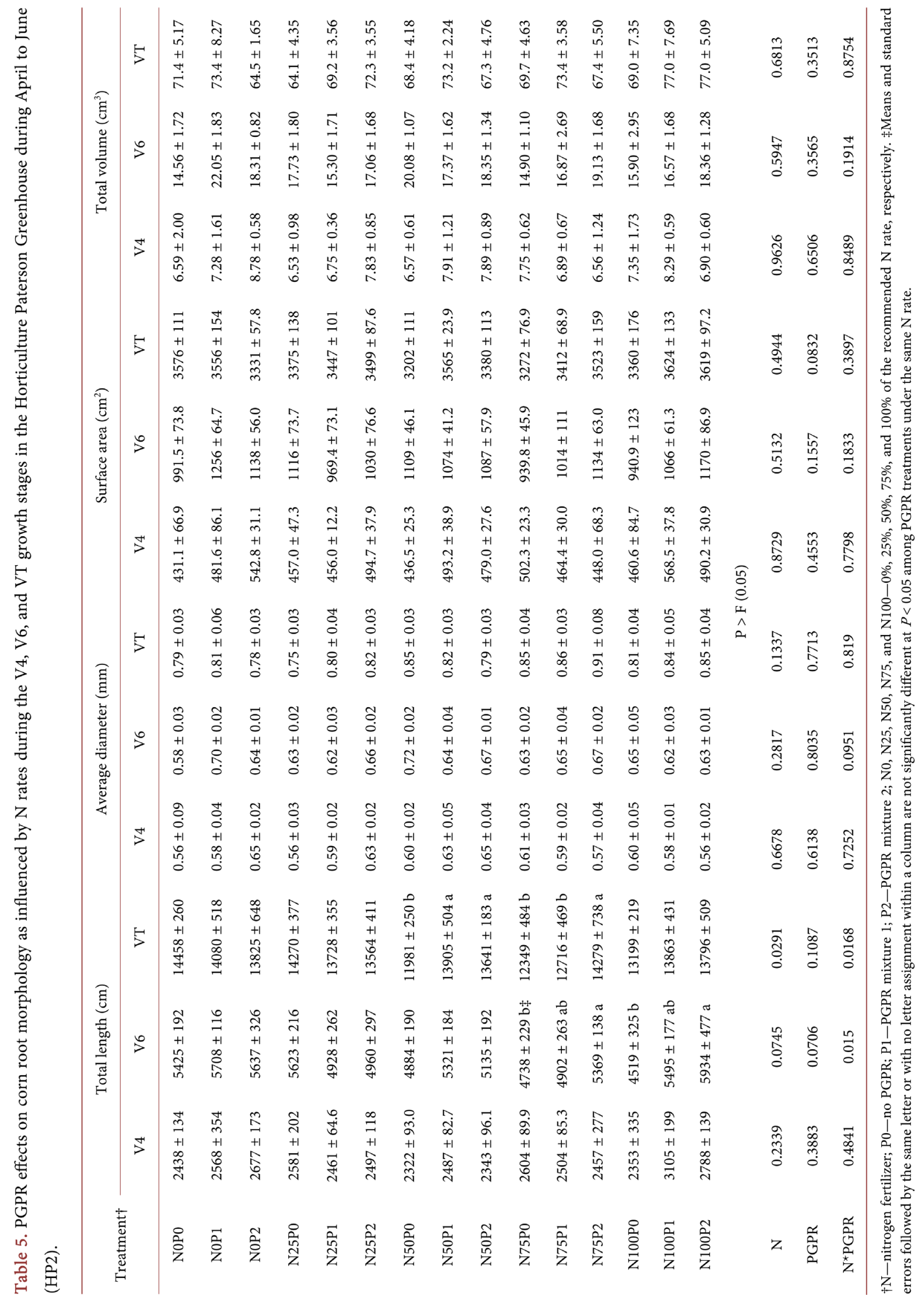


relative high $\mathrm{N}$ levels. At the V4 stage, PGPR mixture 2 (direct comparison between each PGPR at each $\mathrm{N}$ level) significantly increased average root diameter by $5.6 \%$ compared to the no-PGPR control in HP1 (Table 4 ). The PGPR mixture 2 significantly increased total root length by $13.3 \%(P=0.0494)$ and $31.3 \%$ $(P=0.0160)$ with $75 \%$ and $100 \%$ of the recommended $\mathrm{N}$ application rate at the V6 stage and up to $13.9 \%(P=0.0024)$ and $15.6 \%(P=0.0418)$ with $50 \%$ and $75 \%$ of recommended $\mathrm{N}$ rate at the VT stage, respectively. An increase in total root length of $16.1 \%$ ( $P=0.0013)$ was observed with the inoculation of PGPR mixture 1 at the VT stage for half the recommended N rate in HP2 (Table 5). These results indicated that the selected PGPR strains in this experiment could potentially promote root growth even under N-limited conditions. Our results are consistent with those observed in several studies which have indicated that PGPR inoculations effectively increased the root length and surface area [18] [60], suggesting this resulted from PGPR synthesis of phytohormones and other secondary metabolites [61]. It is also worth mentioning that the corn hybrid used in this experiment has a high root strength $(8 / 10)$ which means it has an innate capacity to grow a strong root system, which may have masked some of the potential positive effects of PGPR on root growth.

Root morphological parameters, especially total root length and root surface area, play an important role in the capture of belowground nutrient resources for plant development [62] [63] and root morphological parameters may exhibit higher water retention [64]. Several studies have reported that root structure and morphology are influenced by soil microorganisms such as rhizobacteria [52] [64] [65] [66]. El Zemrany et al. [64] investigated the root characteristics of corn where seeds were inoculated with PGPR Azospirillumlipoferum CRT1 during the early growth stages (for 35 days after planting, DAP) and demonstrated that plants inoculated with PGPR significantly increased root biomass, total root length, and root surface area at 26,30, and 35 DAP. Calvo et al. [52] reported that Bacillus spp. mixtures could increase total root length, root surface area, root volume, and total length of fine roots of corn compared to the non-inoculated control when urea ammonium nitrate (UAN) was present at the V2 stage, while positive effects resulted when calcium ammonium nitrate (CAN) was applied at the V4 stage.

\subsection{Biomass Accumulation and N Uptake}

Significant differences were observed among $\mathrm{N}$ levels for biomass of roots, stems, and leaves. Plant aboveground biomass tended to increase with increasing $\mathrm{N}$ rate at the V6 and VT stages, no significant differences were observed at the V4 stage in both experiments (Table 6, Figure 1 and Figure 2). At the V4 stage, the no $\mathrm{N}$ treatment had the greatest plant biomass when compared with other $\mathrm{N}$ rates with the same PGPR treatment, especially in HP1. The no $\mathrm{N}$ control had the greatest root biomass on average (Figure 1(a)). At the V6 and VT stages, the relative high $\mathrm{N}$ rates (N75 and $\mathrm{N} 100)$ had the greatest plant biomass regardless 


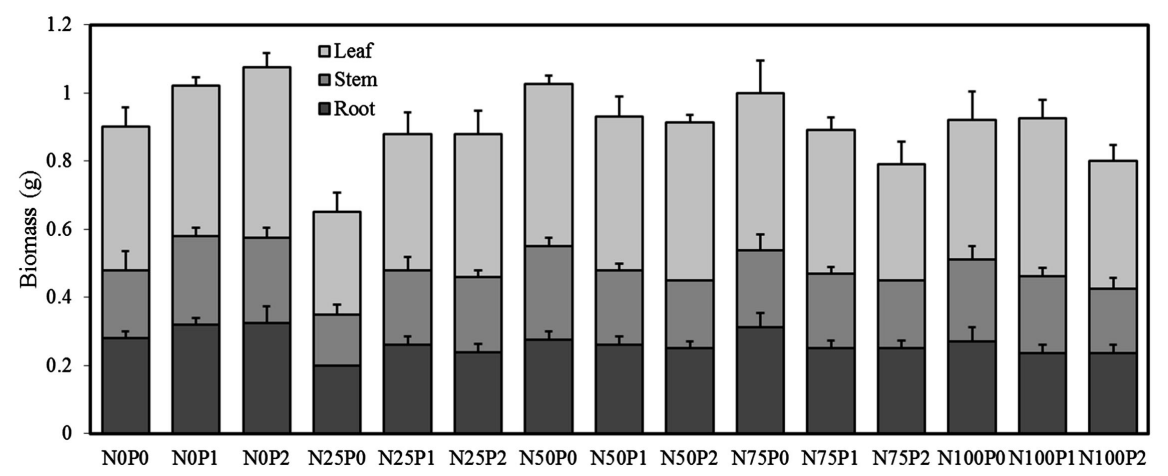

(a)

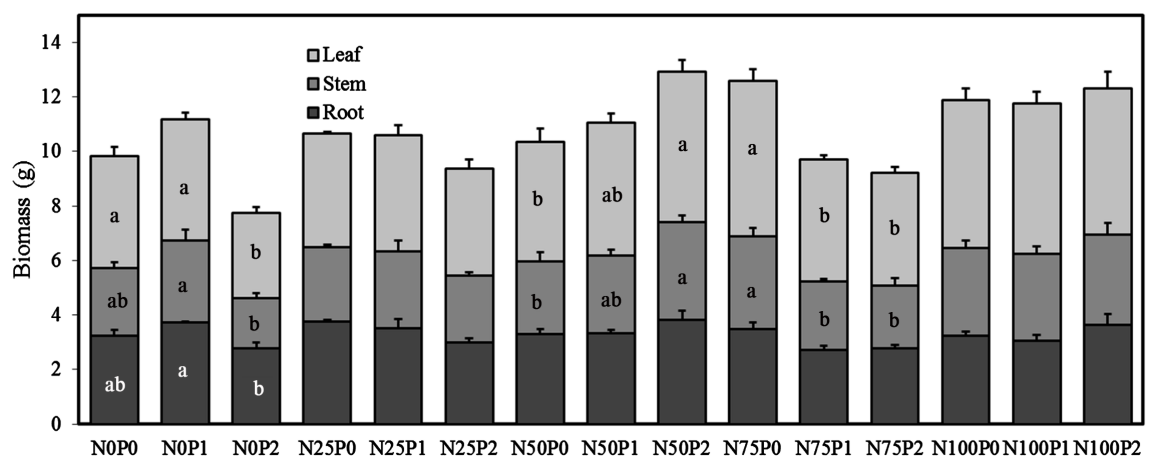

(b)

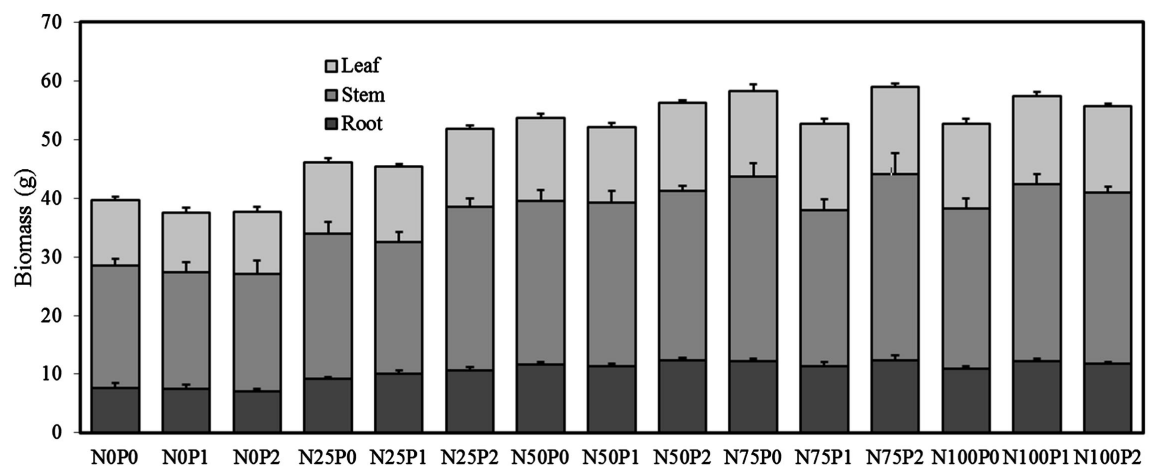

(c)

Figure 1. Corn biomass (dry matter basis) for $\mathrm{N}$ rates as influenced by PGPR inoculation during (a) V4; (b) V6; and (c) VT growth stages in the Horticulture Paterson Greenhouse from March to May (HP1). Data represent means and standard errors of replicates. Within each experimental time, bar segments denoted by the same letter or with no letter assignment are not significantly different at $P<0.05$ among PGPR treatments under the same $\mathrm{N}$ rate.

of PGPR application. The full $\mathrm{N}$ rate treatment increased stem and leaf biomass by $32.4 \%(P=0.0124)$ and $39.9 \%(P=0.0002)$ at the V6 stage and increased root, stem, and leaf biomass by $57.4 \%(P<0.0001), 42.8 \%(P<0.0001)$, and $37.9 \%(P$ $<0.0001)$, respectively, at the VT stage when compared to unfertilized control in HP1. An increased stem biomass of $24.8 \%(P=0.02)$ was observed with the full $\mathrm{N}$ application rate at the VT stage in HP2 (Figure 2(c)). Plants with $50 \%$ and 


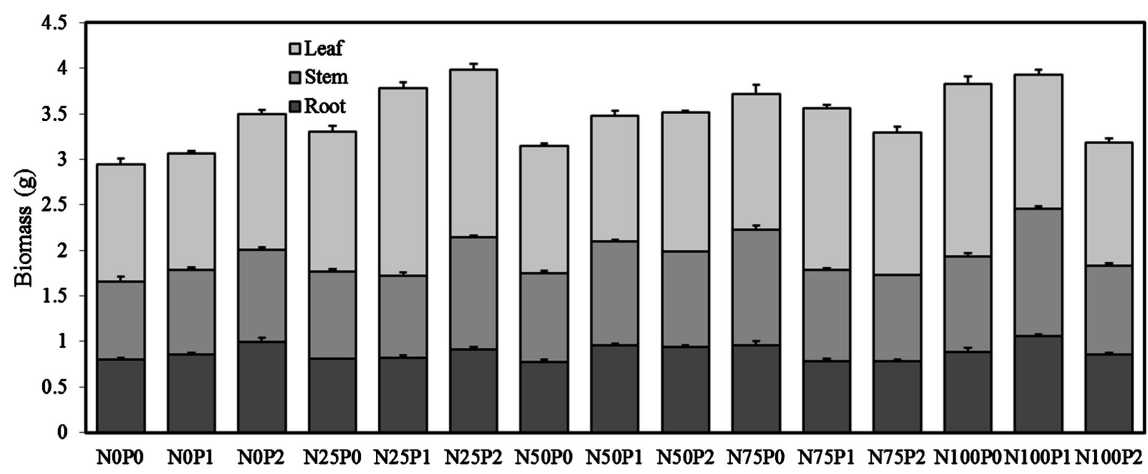

(a)

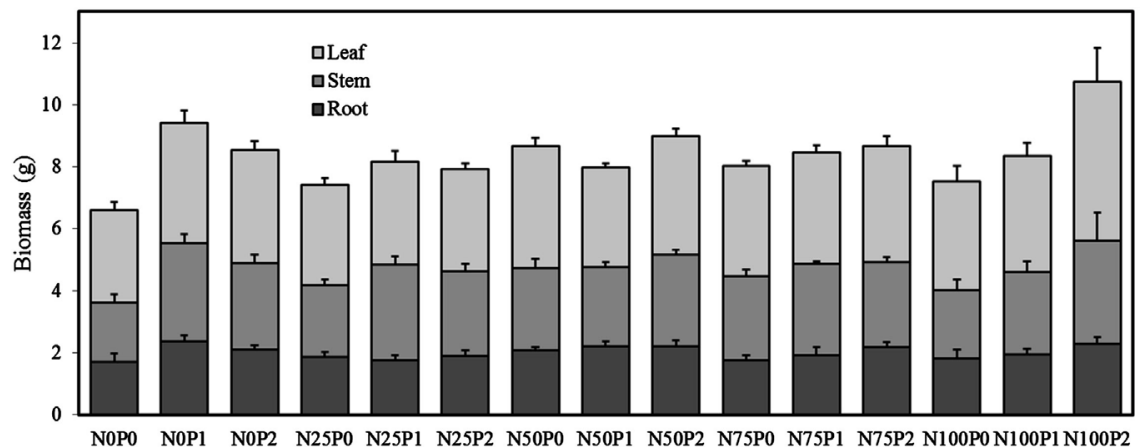

(b)

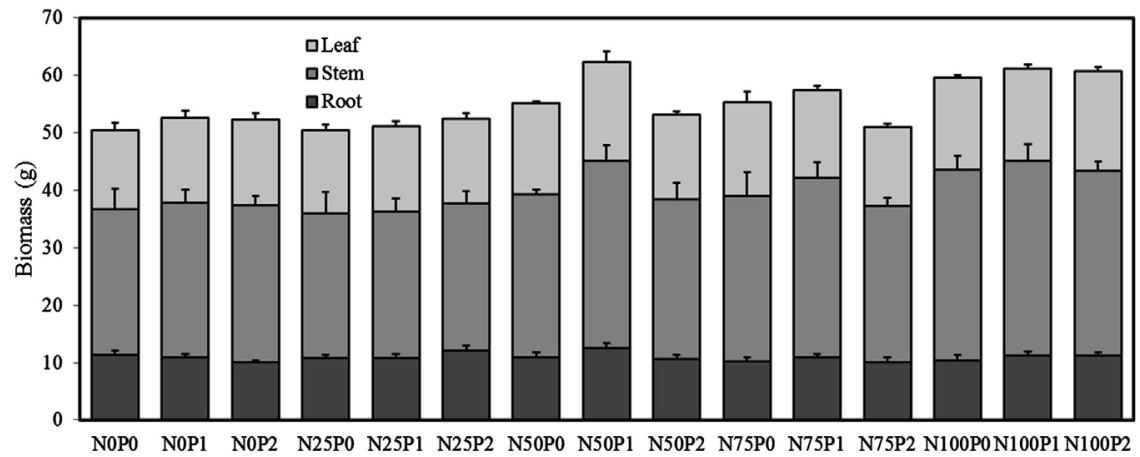

(c)

Figure 2. Corn biomass (dry matter basis) for $\mathrm{N}$ rates as influenced by PGPR inoculation during (a) V4; (b) V6; and (c) VT growth stages in the Horticulture Paterson Greenhouse from April to June (HP2). Data represent means and standard errors of replicates. Within each experimental time, bar segments denoted by the same letter or with no letter assignment are not significantly different at $P<0.05$ among PGPR treatments under the same $\mathrm{N}$ rate.

$75 \%$ of the recommended $\mathrm{N}$ rate also showed significant increases in root, stem, and leaf $(P<0.0001)$ biomass compared to unfertilized control at the VT stage, which was similar to plant biomass of the full rate treatment. Although there were no significant responses to application of the PGPR mixtures on biomass accumulation at some growth stages, corn seeds inoculated with PGPR mixtures had similar or greater plant biomass when compared to non-inoculated seeds under the different $\mathrm{N}$ levels during the growing period (Table 6, Figure 1 and 
Table 6. Analysis of variance results for biomass of root, stem, and leaf at the V4, V6, and VT stages and N concentration of root, stem, and leaf at the VT stage in the Horticulture Paterson Greenhouse during March to May (HP1) and April to June (HP2).

\begin{tabular}{|c|c|c|c|c|c|c|}
\hline \multirow{3}{*}{ Source } & \multicolumn{6}{|c|}{$\mathrm{P}>\mathrm{F}(0.05)$} \\
\hline & \multicolumn{3}{|c|}{ HP1 } & \multicolumn{3}{|c|}{ HP2 } \\
\hline & Root & Stem & Leaf & Root & Stem & Leaf \\
\hline & \multicolumn{6}{|c|}{ Biomass at the V4 stage } \\
\hline $\mathrm{N}$ & 0.0215 & 0.5443 & 0.3490 & 0.9068 & 0.6927 & 0.1424 \\
\hline PGPR & 0.9223 & 0.6643 & 0.8420 & 0.7681 & 0.8807 & 0.8916 \\
\hline \multirow[t]{2}{*}{$\mathrm{N}^{\star P G P R}$} & 0.4215 & 0.3304 & 0.6177 & 0.7303 & 0.5150 & 0.5974 \\
\hline & \multicolumn{6}{|c|}{ Biomass at the V6 stage } \\
\hline $\mathrm{N}$ & 0.1483 & 0.0132 & 0.0001 & 0.3483 & 0.9717 & 0.0972 \\
\hline PGPR & 0.3891 & 0.4976 & 0.3520 & 0.0713 & 0.0075 & 0.0903 \\
\hline \multirow[t]{2}{*}{$\mathrm{N}^{\star P G P R}$} & 0.0113 & 0.0164 & 0.0486 & 0.6981 & 0.3664 & 0.2314 \\
\hline & \multicolumn{6}{|c|}{ Biomass at the VT stage } \\
\hline $\mathrm{N}$ & $<0.0001$ & $<0.0001$ & $<0.0001$ & 0.591 & 0.0050 & 0.0795 \\
\hline PGPR & 0.3464 & 0.1729 & 0.5295 & 0.479 & 0.3985 & 0.6479 \\
\hline \multirow[t]{2}{*}{$\mathrm{N} *$ PGPR } & 0.3480 & 0.4435 & 0.7611 & 0.4965 & 0.9811 & 0.5311 \\
\hline & \multicolumn{6}{|c|}{$\mathrm{N}$ concentration at the VT stage } \\
\hline $\mathrm{N}$ & $<0.0001$ & $<0.0001$ & $<0.0001$ & $<0.0001$ & $<0.0001$ & $<0.0001$ \\
\hline PGPR & 0.7112 & 0.6267 & 0.2639 & 0.7130 & 0.9031 & 0.8717 \\
\hline $\mathrm{N}^{\star} \mathrm{PGPR}$ & 0.1660 & 0.3340 & 0.6033 & 0.0547 & 0.6315 & 0.6244 \\
\hline
\end{tabular}

Figure 2). Both treatments inoculated with PGPR mixtures had greater stem biomass than the non-inoculated control, increasing $21.8 \%$ and $22.9 \%$ with PGPR mixtures $1(P=0.0264)$ and $2(P=0.0151)$, respectively, at the V6 stage in HP2. The improvement of plant biomass by PGPR was only observed at the V6 stage, but not at the V4 and VT stages (Table 6, Figure 1 and Figure 2). The lack of PGPR effects on plants evaluated at the V4 stage may be due to the low rate of biomass accumulation and nutrient uptake during the early corn growth. In contrast, no significant difference between non-PGPR and PGPR treatments on biomass accumulation evaluated at the VT stage may be due to the small amount of nutrients provided by PGPR could not satisfy the high nutrient requirements during the late vegetative growth stage. Nitrogen and PGPR interactions were observed for plant biomass accumulation at the V6 stage in HP1 (Table 6). PGPR mixture 1 with no $\mathrm{N}$ fertilizer (NOP1) had the greatest root, stem, and leaf biomass at the V6 stage, although there were no significant differences observed compared to the non-inoculation control, an increase of 34.8\% ( $P=0.0339), 63.0 \%(P=0.0202)$, and $41.3 \%(P=0.0283)$ occurred when compared to PGPR mixture 2, respectively. PGPR mixture 2 with $50 \%$ of recommended N (N50P2) had the greatest stem and leaf biomass with an increase of $34.4 \%(P=0.0461)$ and $25.6 \%(P=0.0495)$ compared to the N50P0 treatment 
at the V6 stage, respectively. However, at 75\% of recommended $\mathrm{N}$ rate, inoculation of PGPR strains had no benefit on aboveground biomass accumulation, even showed lower stem and leaf biomass than the no-PGPR control at the V6 stage. These results indicated that PGPR inoculation induced an increase of plant biomass that was slightly greater than the non-PGPR treatment at the different $\mathrm{N}$ levels, especially with low or half-rate $\mathrm{N}$ application.

Plant tissue $\mathrm{N}$ concentrations were significantly different among $\mathrm{N}$ treatments, with $\mathrm{N}$ concentrations tending to increase with increasing $\mathrm{N}$ rate regardless of whether the PGPR inoculants were added or not at the VT stage for both experimental times (Table 6 and Figure 3). Plants receiving 75\% and the full $\mathrm{N}$ rate had significantly greater root, stem, and leaf $\mathrm{N}$ concentration compared to $25 \%$ of recommended $\mathrm{N}$ rate and unfertilized control, while the half $\mathrm{N}$ rate treatments also significantly increased plant tissue $\mathrm{N}$ concentrations compared to the unfertilized control (Figure 3).
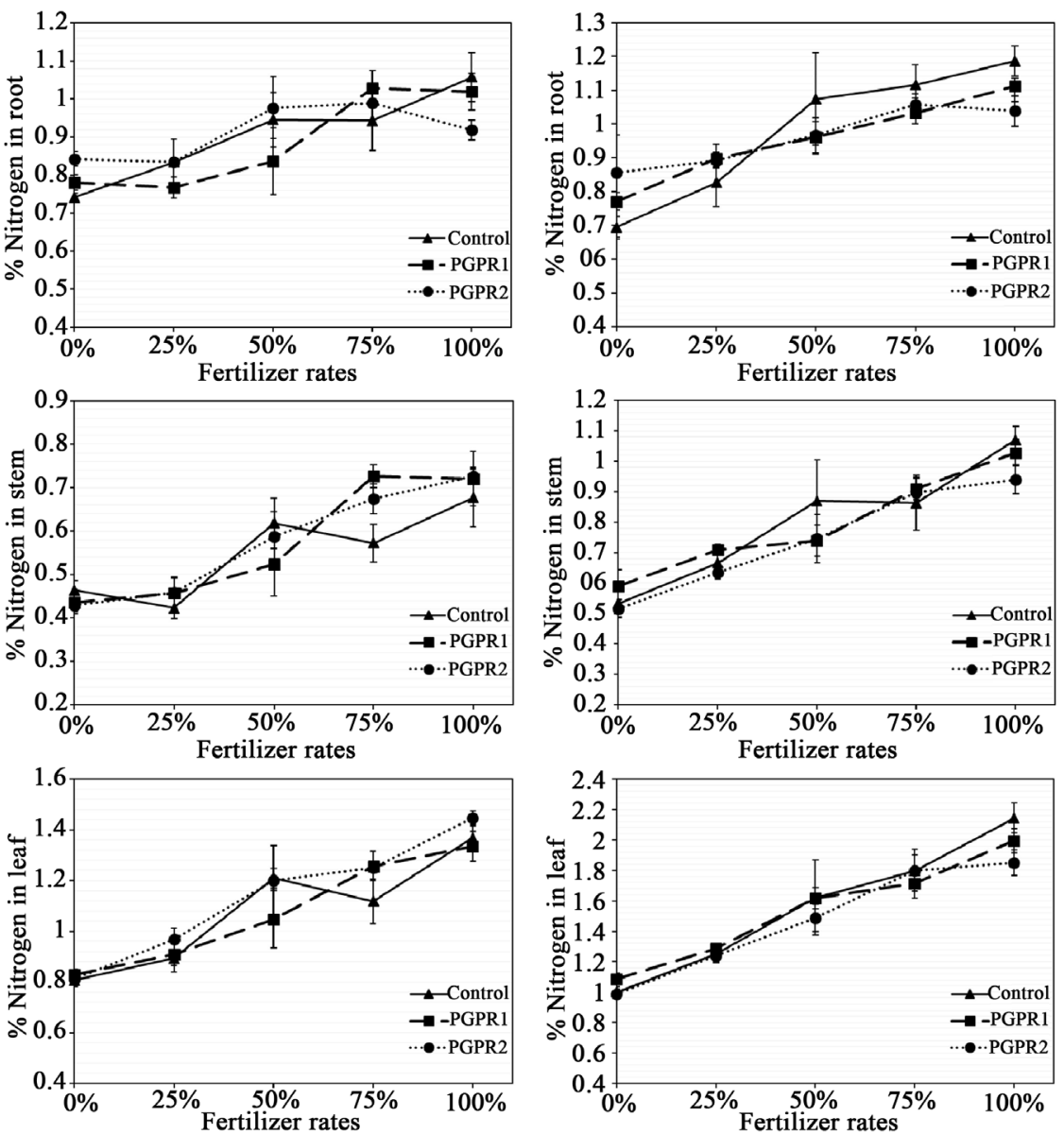

Figure 3. Nitrogen concentration (\%) in root, stem, and leaf at different $\mathrm{N}$ rates as influenced by PGPR inoculation at the VT stage in the Horticulture Paterson Greenhouse from March to May (left) and from April to June (right). Fertilizer rates are percentages of the $100 \%$ rate $\left(135 \mathrm{~kg} \mathrm{~N} \mathrm{ha}^{-1}\right.$ ) recommended by Alabama Cooperative Extension System for corn on a Coastal Plain soil. Data represent means and standard errors of replicates. 
Plant tissue $\mathrm{N}$ concentrations compared to the unfertilized control are shown in Figure 3. These results indicated that under a properly managed greenhouse condition that prevented nutrient loss through leaching, $50 \%$ or $75 \%$ of the recommended $\mathrm{N}$ rate could satisfy plant $\mathrm{N}$ requirements during the vegetative growth stages, which may mask the positive effects of inoculated PGPR strains [67]. No significant differences were observed for the response of corn $\mathrm{N}$ concentrations to PGPR inoculation (Figure 3). Also, there was no N and PGPR interaction observed for plant tissue $\mathrm{N}$ concentrations (Table 6). However, PGPR applications resulted in equivalent or greater plant tissue $\mathrm{N}$ concentrations compared to non-PGPR treatments under low $\mathrm{N}$ level conditions, while a slightly lower plant tissue $\mathrm{N}$ concentration was observed when PGPR inoculations were combined with relative high $\mathrm{N}$ rates. This may be due to the dilution effect from greater plant tissue biomass. The results of leaf $\mathrm{N}$ concentration were consistent with the results of SPAD readings (Table 2 and Table 3 ) due to the high positive correlation between these two parameters [52] [68] [69]. These results indicated the capacity of PGPR to improve NUE of corn under N limited conditions and a potential for increased corn yield. Generally, the Bacillus spp. strains could increase $\mathrm{N}$ uptake by various mechanisms, such as producing phytohormones, solubilizing soil nutrients, enhancing root growth (root length and surface area) for nutrient absorption [70] [71] [72].

In our experiment, PGPR mixture 1 had a greater effect on increasing plant biomass accumulation under conditions where no $\mathrm{N}$ was added, while PGPR mixture 2 had a greater benefit in increasing plant biomass accumulation with half the recommended $\mathrm{N}$ rate. Both microbial inoculants had a tendency to improve plant tissue $\mathrm{N}$ concentrations. Our results for plant biomass and $\mathrm{N}$ concentration were consistent with previous studies that have shown the positive effects of PGPR inoculation on plant dryweight and N uptake of corn [26] [30] [47] [72] [73]. Biari et al. [73] indicated that inoculation of PGPR strains can increase corn growth parameters, such as plant height and shoot dry weight and also enhance grain dry weight and seed quality (100-seed weight and nutrients content). Therefore, PGPR treatments in our experiment that enhanced plant growth parameters and biomass accumulation could lead to a potential increase in corn yield. In addition, these positive effects of PGPR are mainly attributed to its capacity to promote better absorption of essential nutrients that are responsible for the high rate of photosynthesis [52] [73]. Consistently, a stronger root system, greater SPAD reading and dry weight biomass were observed with PGPR application in our experiment.

\section{Conclusion}

Overall the selected PGPR mixtures applied with half the recommended $\mathrm{N}$ rate promoted corn growth and produced corn biomass and tissue $\mathrm{N}$ concentrations equal to or greater than that of the full $\mathrm{N}$ fertilization rate under greenhouse conditions. The high amounts of $\mathrm{N}$ fertilization may have masked the potential 
effect of PGPR inoculations, especially in the late growing stages of corn. Therefore, PGPR inoculants should be considered as tools that will complement nutrient efficiency practices by increasing the plant's nutrient uptake efficiency, thereby reducing $\mathrm{N}$ losses and reducing the amount of applied N. Further studies are needed in order to determine the threshold of $\mathrm{N}$ fertilization reduction that could be achieve when PGPR inoculants are applied to different crops and with different types of nitrogen fertilizers, as well as investigate the optimal field management practices for simulating the efficacy of PGPR under field conditions.

\section{Conflicts of Interest}

The authors declare no conflicts of interest regarding the publication of this paper.

\section{References}

[1] Malik, A.S., Boyko, O., Atkar, N. and Young, W.F. (2001) A Comparative Study of MR Imaging Profile of Titanium Pedicle Screws. Acta Radiologica, 42, 291-293. https://doi.org/10.1080/028418501127346846

[2] Hu, T. and Desai, J.P. (2004) Soft-Tissue Material Properties under Large Deformation: Strain Rate Effect. Proceedings of the 26th Annual International Conference of the IEEE EMBS, San Francisco, CA, 1-5 September 2004, 2758-2761. https://doi.org/10.1109/IEMBS.2004.1403789

[3] Ortega, R., Loria, A. and Kelly, R. (1995) A Semiglobally Stable Output Feedback PI2D Regulator for Robot Manipulators. IEEE Transactions on Automatic Control, 40, 1432-1436. https://doi.org/10.1109/9.402235

[4] Wit, E. and McClure, J. (2004) Statistics for Microarrays: Design, Analysis, and Inference. 5th Edition, John Wiley \& Sons Ltd., Chichester.

[5] Prasad, A.S. (1982) Clinical and Biochemical Spectrum of Zinc Deficiency in Human Subjects. In: Prasad, A.S., Ed., Clinical, Biochemical and Nutritional Aspects of Trace Elements, Alan R. Liss, Inc., New York, 5-15.

[6] Giambastiani, B.M.S. (2007) EvoluzioneIdrologicaedIdrogeologica Della Pineta di san Vitale (Ravenna). Ph.D. Thesis, Bologna University, Bologna.

[7] Wu, J.K. (1994) Two Problems of Computer Mechanics Program System. Proceedings of Finite Element Analysis and CAD, Peking University Press, Beijing, 9-15.

[8] Honeycutt, L. (1998) Communication and Design Course. http://dcr.rpi.edu/commdesign/class1.html

[9] Wright, O. and Wright, W. (1906) Flying-Machine. US Patent No. 821393.

[10] Tilman, D (1998). The Greening of the Green Revolution. Nature, 396, 211-212. https://doi.org/10.1038/24254

[11] Gadagi, R.S., Krishnaraj, P.U., Kulkarni, J.H. and Sa, T. (2004) The Effect of Combined Azospirillum Inoculation and Nitrogen Fertilizer on Plant Growth Promotion and Yield Response of the Blanket Flower Gaillardia pulchella. Scientia Horticulturae, 100, 323-332. https://doi.org/10.1016/j.scienta.2003.10.002

[12] Adesemoye, A.O., Torbert, H.A. and Kloepper, J.W. (2008) Enhanced Plant Nutrient Use Efficiency with PGPR and AMF in an Integrated Nutrient Management 
System. Canadian Journal of Microbiology, 54, 876-886. https://doi.org/10.1139/W08-081

[13] Adesemoye, A.O. and Kloepper, J.W. (2009) Plant-Microbes Interactions in Enhanced Fertilizer-Use Efficiency. Applied Microbiology and Biotechnology, 85, 1-12. https://doi.org/10.1007/s00253-009-2196-0

[14] Cong, P.T., Dung, T.D., Hien, T.M., Hien, N.T., Choudhury, A.T., Kecskes, M.L. and Kennedy, I.R. (2009) Inoculant Plant Growth-Promoting Microorganisms Enhance Utilization of Urea-N and Grain Yield of Paddy Rice in Southern Vietnam. European Journal of Soil Biology, 45, 52-61. https://doi.org/10.1016/j.ejsobi.2008.06.006

[15] Ahmad, S., Imran, M., Hussain, S., Mahmood, S., Hussain, A. and Hasnain, M. (2017) Bacterial Impregnation of Mineral Fertilizers Improves Yield and Nutrient Use Efficiency of Wheat. Journal of the Science of Food and Agriculture, 97, 36853690. https://doi.org/10.1002/jsfa.8228

[16] Kloepper, J.W., Lifshitz, R. and Zablotowicz, R.M. (1989) Free Living Bacterial Inocula for Enhancing Crop Productivity. Trends in Biotechnology, 7, 39-44. https://doi.org/10.1016/0167-7799(89)90057-7

[17] Kloepper, J.W., Zablotowick, R.M., Tipping, E.M. and Lifshitz, R. (1991) Plant Growth Promotion Mediated by Bacterial Rhizosphere Colonizers. In: Keister, D.L. and Cregan, P.B., Eds., The Rhizosphere and Plant Growth, Kluwer Academic Press, Dordrecht. https://doi.org/10.1007/978-94-011-3336-4_70

[18] Canbolat, M.Y., Bilen, S., Çakmakçı, R., Şahin, F. and Aydın, A. (2006) Effect of Plant Growth-Promoting Bacteria and Soil Compaction on Barley Seedling Growth, Nutrient Uptake, Soil Properties and Rhizosphere Microflora. Biology and Fertility of Soils, 42, 350-357. https://doi.org/10.1007/s00374-005-0034-9

[19] Adesemoye, A.O., Torbert, H.A. and Kloepper, J.W. (2009) Plant Growth-Promoting Rhizobacteria Allow Reduced Application Rates of Chemical Fertilizers. Microbial Ecology, 58, 921-929. https://doi.org/10.1007/s00248-009-9531-y

[20] Figueiredo, M., Seldin, L., Araujo, F. and Mariano, R. (2010) Plant Growth Promoting Rhizobacteria: Fundamentals and Applications. In: Maheshwari, D.K., Ed, Plant Growth and Health Promoting Bacteria, Springer, Berlin, 21-43. https://doi.org/10.1007/978-3-642-13612-2_2

[21] Kumar, S., Pandey, P. and Maheshwari, D.K. (2009) Reduction in Dose of Chemical Fertilizers and Growth Enhancement of Sesame (Sesamum indicum L.) with Application of Rhizospheric Competent Pseudomonas Aeruginosa LES4. European Journal of Soil Biology, 45, 334-340. https://doi.org/10.1016/j.ejsobi.2009.04.002

[22] Shahzad, S.M., Arif, M.S., Riaz, M., Iqbal, Z. and Ashraf, M. (2013) PGPR with Varied ACC-Deaminase Activity Induced Different Growth and Yield Response in Maize (Zea mays L.) under Fertilized Conditions. European Journal of Soil Biology, 57, 27-34. https://doi.org/10.1016/j.ejsobi.2013.04.002

[23] Wong, W.T., Tseng, C.H., Hsu, S.H., Lur, H.S., Mo, C.W., Huang, C.N., Hsu, S.C., Lee, K.T. and Liu, C.T. (2014) Promoting Effects of a Single Rhodopseudomonas palustris Inoculant on Plant Growth by Brassica rapachinensis under Low Fertilizer Input. Microbes and Environments, 29, 303-313.

https://doi.org/10.1264/jsme2.ME14056

[24] Kumar, A., Prakash, A. and Johri, B.N. (2011) Bacillus as PGPR in Crop Ecosystem. In: Maheshwari, D.K., Ed., Bacteria in Agrobiology: Crop Ecosystems, Springer, Heidelberg, Berlin, 37-59. https://doi.org/10.1007/978-3-642-18357-7_2 
[25] Mandic-Mulec, I. and Prosser, J.I. (2011) Diversity of Endospore-Forming Bacteria in Soil: Characterization and Driving Mechanisms. In: Logan, A.N. and Vos, P., Eds., Endospore-Forming Soil Bacteria, Springer, Heidelberg Berlin, 31-59. https://doi.org/10.1007/978-3-642-19577-8_2

[26] Huang, X., Zhou, D., Guo, J., Manter, D.K., Reardon, K.F. and Vivanco, J.M. (2015) Bacillus spp. from Rainforest Soil Promote Plant Growth under Limited Nitrogen Conditions. Journal of Applied Microbiology, 118, 672-684. https://doi.org/10.1111/jam.12720

[27] Wani, P.A. and Khan, M.S. (2010) Bacillus Species Enhance Growth Parameters of Chickpea (Cicerarietinum L.) in Chromium Stressed Soils. Food and Chemical Toxicology, 48, 3262-3267. https://doi.org/10.1016/j.fct.2010.08.035

[28] Meng, Q., Jiang, H. and Hao, J. (2016) Effects of Bacillus velezensis Strain BAC03 in Promoting Plant Growth. Biological Control, 98, 18-26.

https://doi.org/10.1016/j.biocontrol.2016.03.010

[29] de Freitas, J.R., Banerjee, M.R. and Germida, J.J. (1997) Phosphate-Solubilizing Rhizobacteria Enhance the Growth and Yield But Not Phosphorus Uptake of Canola (Brassica napus L.). Biology and Fertility of Soils, 24, 358-364. https://doi.org/10.1007/s003740050258

[30] Kuan, K.B., Othman, R., Rahim, K.A. and Shamsuddin, Z.H. (2016) Plant GrowthPromoting Rhizobacteria Inoculation to Enhance Vegetative Growth, Nitrogen Fixation and Nitrogen Remobilization of Maize under Greenhouse Conditions. PLoS ONE, 11, e0152478. https://doi.org/10.1371/journal.pone.0152478

[31] Bullied, W.J., Buss, T.J. and Vessey, J.K. (2002) Bacillus cereus UW85 Inoculation Effects on Growth, Nodulation, and N Accumulation in Grain Legumes: Field Studies. Canadian Journal of Plant Science, 82, 291-298. https://doi.org/10.4141/P01-048

[32] Çakmakçi, R., Donmez, F., Aydin, A. and Sahin, F. (2006) Growth Promotion of Plants by Plant Growth-Promoting Rhizobacteria under Greenhouse and Two Different Field Soil Conditions. Soil Biology and Biochemistry, 38, 1482-1487. https://doi.org/10.1016/j.soilbio.2005.09.019

[33] de Freitas, J.R. (2000) Yield and N Assimilation of Winter Wheat (Triticum aestivum L., var. Norstar) Inoculated with Rhizobacteria. Pedobiologia, 44, 97-104. https://doi.org/10.1078/S0031-4056(04)70031-1

[34] Lucy, M., Reed, E. and Click, B.R. (2004) Application of Free Living Plant GrowthPromoting Rhizobacteria. Antonic Van Leewenhoek, 86, 1-25. https://doi.org/10.1023/B:ANTO.0000024903.10757.6e

[35] Belimov, A.A., Kojemiakov, A.P. and Chuvarliyeva, C.V. (1995) Interaction between Barley and Mixed Cultures of Nitrogen Fixing and Phosphate-Solubilizing Bacteria. Plant and Soil, 173, 29-37. https://doi.org/10.1007/BF00155515

[36] Ryu, C.M., Murphy, J.F., Reddy, M.S. and Kloepper, J.W. (2007) A Two-Strain Mixture of Rhizobacteria Elicits Induction of Systemic Resistance against Pseudomonas syringae and Cucumber mosaic virus Coupled to Promotion of Plant Growth on Arabidopsis thaliana. Journal of Microbiology and Biotechnology, 17, 280-286.

[37] Jarak, M., Mrkovački, N., Bjelić, D., Jošić, D., Hajnal-Jafari, T. and Stamenov, D. (2012) Effects of Plant Growth Promoting Rhizobacteria on Maize in Greenhouse and Field Trial. African Journal of Microbiology Research, 6, 5683-5690. https://doi.org/10.5897/AJMR12.759

[38] Egamberdiyeva, D. (2007) The Effect of Plant Growth Promoting Bacteria on Growth 
and Nutrient Uptake of Maize in Two Different Soils. Applied Soil Ecology, 36, 184-189. https://doi.org/10.1016/j.apsoil.2007.02.005

[39] Shaharoona, B., Naveed, M., Arshad, M. and Zahir, Z.A. (2008) Fertilizer-Dependent Efficiency of Pseudomonads for Improving Growth, Yield, and Nutrient Use Efficiency of Wheat (Triticum aestivumL.). Journal of Microbiology and Biotechnology, 79, 147-155. https://doi.org/10.1007/s00253-008-1419-0

[40] Hue, N.V. and Evans, C.E. (1986) Procedures Used for Soil and Plant Analysis by the Auburn University Soil Testing Laboratory. Auburn University, Auburn.

[41] Mitchell, C.C. and Huluka, G. (2012) Nutrient Recommendation Tables for Alabama Crops. Agronomy and Soils Departmental Series No. 324B. Alabama Agricultural Experiment Station, Auburn, AL. http://www.aces.edu/anr/soillab/forms/documents/ay-324B.pdf

[42] Bauhus, J. and Messier, C. (1999) Evaluation of Fine Root Length and Diameter Measurements Obtained Using RHIZO Image Analysis. Agronomy Journal, 91, 142147. https://doi.org/10.2134/agronj1999.00021962009100010022x

[43] Costa, C., Dwyer, L.M., Hamilton, R.I., Hamel, C., Nantais, L. and Smith, D.L. (2000) A sampling Method for Measurement of Large Root Systems with Scanner-Based Image Analysis. Agronomy Journal, 92, 621-627.

https://doi.org/10.2134/agronj2000.924621x

[44] SAS Institute (2013) Version 9.4. SAS Institute, Cary, NC.

[45] Akintoye, H.A. (1996) Thesis Abstract. The International Institute of Tropical Agriculture Research, 25-27.

[46] LustosaFilho, J.F., Nőbrega, CA, Nőbrega, R.S.A., Andrade, F.R., Pacheco, L.P., Pires, L.C. and de Aquino, J.M. (2014) Effect of Rates and Forms of Nitrogen Splitting on Corn in the Brazilian Cerrado of Piauí State. African Journal Agricultural Research, 9, 2648-2656. https://doi.org/10.5897/AJAR2014.8710

[47] Marini, D., Guimarães, V.F., Dartora, J., Lana, M.C. and Pinto Jr., A.S. (2015) Growth and Yield of Corn Hybrids in Response to Association with Azospirillum brasilense and Nitrogen Fertilization. Revista Ceres Viçosa, 62, 117-123. https://doi.org/10.1590/0034-737X201562010015

[48] Arnon, I. (1975) Mineral Nutrition of Maize. International Potash Institute, Bern, 454.

[49] Fancelli, A.L. and Dourado-Neto, D. (2000) Produção de milho. Agropecuária, Guaíba, $360 \mathrm{p}$

[50] Amin, M.E.H. (2011) Effect of Different Nitrogen Sources on Growth, Yield and Quality of Fodder Maize (Zea mays L.). Journal of the Saudi Society of Agricultural Sciences, 10, 17-23. https://doi.org/10.1016/j.jssas.2010.06.003

[51] Dicko, A.H. and Verma, R.K. (2014) Effect of Growth Promoting Microbes on Initial Growth of Maize. Indian Journal of Tropical Biodiversity, 22, 64-69.

[52] Calvo, P., Watts, D.B., Kloepper, J.W. and Torbert, H.A. (2017) Effects of Microbial-Based Inoculants on Nutrient Concentrations and Early Root Morphology of Corn (Zea mays). Journal of Plant Nutrition and Soil Science, 180, 56-70. https://doi.org/10.1002/jpln.201500616

[53] Gholami, A., Biyari, A., Gholipoor, M. and Rahmani, H.A. (2012) Growth Promotion of Maize (Zea mays L.) by Plant-Growth-Promoting Rhizobacteria under Field Conditions. Communications in Soil Science and Plant Analysis, 43, 1263-1272. https://doi.org/10.1080/00103624.2012.666302

[54] Picazevicz, A.A.C., Kusdra, J.F. and Moreno, A.D. (2017) Maize Growth in Res- 
ponse to Azospirillum brasilense, Rhizobium tropici, Molybdemum and Nitrogen. RevistaBrasileira de EngenhariaAgrícola e Ambiental, 21, 623-627. https://doi.org/10.1590/1807-1929/agriambi.v21n9p623-627

[55] Nezarat, S. and Gholami, A. (2009) Screening Plant Growth Promoting Rhizobacteria for Improving Seed Germination, Seedling Growth and Yield of Maize. Pakistan Journal of Biological Sciences, 12, 26-32. https://doi.org/10.3923/pjbs.2009.26.32

[56] Sengupta, C., Bhosale, A. and Malusare, S. (2015) Effect of Plant Growth Promoting Rhizobacteria on Seed Germination and Seedling Development of Zea mays. IJRAT. Special Issue National Conference "AGGT 2015”, 32-40.

[57] Carlier, E., Rovera, M., Rossi, J. and Rosas, S.B. (2008) Improvement of Growth, under Field Conditions, of Wheat Inoculated with Pseudomonas chlororaphis subsp. aurantiaca SR1. World Journal of Microbiology \& Biotechnology, 24, 2653-2658. https://doi.org/10.1007/s11274-008-9791-6

[58] Zabihi, H.R., Savaghebi, G.R., Khavazi, K., Ganjali, A. and Miransari, M. (2010) Pseudomonas Bacteria and Phosphorous Fertilization, Affecting Wheat (Triticum aestivum L.) Yield and P Uptake under Greenhouse and Field Conditions. Acta Physiologiae Plantarum, 33, 145-152. https://doi.org/10.1007/s11738-010-0531-9

[59] Miransari, M. (2011) Soil Microbes and Plant Fertilization. Applied Microbiology and Biotechnology, 92, 875-885. https://doi.org/10.1007/s00253-011-3521-y

[60] Bashan, Y., Holguin, G. and de-Bashan, L.E. (2004) Azospirillum-Plant Relationships: Physiological, Molecular, Agricultural, and Environmental Advances. Canadian Journal of Microbiology, 50, 521-577. https://doi.org/10.1139/w04-035

[61] Vacheron, J., Desbrosses, G., Bouffaud, M.L., Touraine, B., Moënne-Loccoz, Y., Muller, D., Legendre, L., Wisniewski-Dye, F. and Prigent-Combaret, C. (2013) Plant Growth-Promoting Rhizobacteria and Root System Functioning. Frontiers in Plant Science, 4, 356. https://doi.org/10.3389/fpls.2013.00356

[62] Sattelmacher, B., Klotz, F. and Marschner, H. (1990) Influence of the Nitrogen Level on Root Growth and Morphology of Two Potato Varieties Differing in Nitrogen Acquisition. Plant and Soil, 123, 131-137. https://doi.org/10.1007/BF00011258

[63] Kramer, P. and Boyer, J. (1995) Water Relations of Plants and Soils. Academic Press, London, UK. https://doi.org/10.1016/B978-012425060-4/50003-6

[64] El Zemrany, H., Czarnes, S., Hallett, P.D., Alamercery, S., Bally, R. and Jocteur Monrozier, L.J. (2007) Early Changes in Root Characteristics of Maize (Zea mays L.) Following Seed Inoculation with the PGPR Azospirillum lipoferum CRT1. Plant and Soil, 291, 109-118. https://doi.org/10.1007/s11104-006-9178-0

[65] Gamalero, E., Trotta, A., Massa, N., Copetta, A., Martinotti, M.G. and Berta, G. (2004) Impact of Two Fluorescent Pseudomonads and an Arbuscular Mycorrhizal Fungus on Tomato Plant Growth, Root Architecture and P Acquisition. Mycorrhiza, 14, 185-192. https://doi.org/10.1007/s00572-003-0256-3

[66] Lemanceau, P., Offre, P., Mougel, C., Gamalero, E., Dessaux, Y., Moënne-Loccoz, Y. and Berta, G. (2005) Microbial Ecology of the Rhizosphere. In: Bloem, J., Hopkins, D.W. and Benedetti, A., Eds., Microbiological Methods for Assessing Soil Quality, JCABI Publishing, Wallingford, UK, 228-230.

[67] Lin, Y., Watts, D.B., Kloepper, J.W. and Torbert, H.A. (2017) Influence of Plant Growth-Promoting Rhizobacteria on Corn Growth under Different Fertility Sources. Communication in Soil Science and Plant Analysis, 49, 1239-1255. https://doi.org/10.1080/00103624.2018.1457155 
[68] Subedi, K.D. and Ma, B.L. (2009) Corn Crop Production: Growth, Fertilization and Yield. In: Danforth, A.T., Ed, Corn Crop Production: Growth, Fertilization and Yield, Nova Science Publishers, Hauppauge, NY, 1-84.

[69] Zhu, J., Liang, Y. and Tremblay, N. (2011) Responses of Nitrogenvstatus Indicators to Nitrogen Rates and Soil Moisture in Corn (Zea mays L.). Acta Agronomica Sinica, 37, 1259-1265. https://doi.org/10.1016/S1875-2780(11)60035-7

[70] Mantelin, S. and Touraine, B. (2004) Plant Growth-Promoting Bacteria and Nitrate Availability: Impacts on Root Development and Nitrate Uptake. Journal of Experimental Botany, 55, 27-34. https://doi.org/10.1093/jxb/erh010

[71] Idris, E.E.S., Iglesias, D.J., Talon, M. and Borriss, R. (2007) Tryptophan-Dependent Production of Indole-3-Acetic Acid (IAA) Affects Level of Plant Growth Promotion by Bacillus amyloliquefaciens FZB42. Molecular Plant-Microbe Interactions, 20, 619-626. https://doi.org/10.1094/MPMI-20-6-0619

[72] Calvo, P. (2013) Effect of Microbial Inoculation on Nitrogen Plant Uptake and Nitrogen Losses from Soil and Plant-Soil Systems. Doctoral Dissertation, Auburn University, Auburn, AL.

[73] Biari, A., Gholami, A. and Rahmani, R.A. (2008) Growth Promotion and Enhanced Nutrient Uptake of Maize (Zea mays L.) by Application of Plant Growth Promoting Rhizobacteria in Arid Region of Iran. Journal of Biological Sciences, 8, 1015-1020. https://doi.org/10.3923/jbs.2008.1015.1020 